\title{
Brushes with Fame: Thackeray and the Work of Celebrity
}

\author{
NICHOLAS DAMES
}

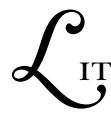

ITTLE is known about the first voyage of William Makepeace Thackeray to England, at the age of five, from his birthplace in Calcutta, but what we do know of this trip involves the sighting of what we might now, with a debt to Thackeray himself, call a celebrity. On 8 March 1817 the Indiaman Prince Regent put in at St. Helena, and Lawrence Barlow, Thackeray's native servant, escorted his charge inland. ${ }^{1}$ As Thackeray was later to remember it in his 1855 lectures on The Four Georges: "[Barlow] took me [on] a long walk over rocks and hills until we reached a garden, where we saw a man walking. 'That is he,' said [Barlow]; 'that is Bonaparte! He eats three sheep every day, and all the little children he can lay his hands on!" ${ }^{2}$ While Thackeray left out so much else of the voyage, which involved his departure from his mother and five months of difficult travel to an entirely unknown locale, this one incident - a casual encounter with fame-persisted

Nineteenth-Century Literature, Vol. 56, No. 1, pp. 23-51. ISSN: 0891-9356.

(C) 2001 by The Regents of the University of California/Society. All rights reserved.

Send requests for permission to reprint to: Rights and Permissions, University of California Press, Journals Division, 2000 Center Street, Suite 303, Berkeley, CA 94704-1 223.

1 See Gordon N. Ray, Thackeray: The Uses of Adversity, I 8 I I-I 846 (New York: McGrawHill, 1955 ), pp. $65-66$, for the few details of the voyage that have emerged subsequent to Thackeray's death.

2 Thackeray, The Four Georges, in The Works of William Makepeace Thackeray, Kensington Edition, 32 vols. (New York: Charles Scribner's Sons, 1904), xxvi, 7o. Hereafter referred to as Works. 
in his memory. Three times Thackeray sent fictional characters on similar, if usually belated, pilgrimages: in Pendennis (1848) Colonel Altamont brags of having seen and been presented to Napoleon at St. Helena; and in The Newcomes (1853-55) both Clive Newcome and his father, Colonel Newcome, visit Napoleon's tomb on trips from India. Thackeray's biographers and critics have continued to mention the anecdote from his first voyage to England, and it has provided rich thematic material, particularly in relation to the deeply equivocal role of servants in his mature work. ${ }^{3}$ One simple fact about this scene, however, has remained unnoticed: its survival as Thackeray's only recollection of this most pivotal voyage. What replaces or displaces memories more familial, possibly more traumatic, and certainly more personal, is a brush with fame - a brush so incidental as to have left nothing but Barlow's words and Bonaparte's image, yet so vivid as to have mnemonic priority.

This scene suggests to us a process of consciousness whereby our personal circumstances yield in importance to the sudden, and not-to-be-forgotten, collision with fame of an unprecedented and even monstrous sort. This process is so continual in Thackeray's fiction that we can adduce it as a general rule: fame has a cognitive and mnemonic appeal that overrules, and might even organize, merely individual facts. Put another way, the allure of a public world of fame extends its reach into and over a realm of memory and desire that is only putatively private. Even as the brushes with fame in Thackeray's fiction diminish toward a fame of an increasingly attenuated sort, from the deposed Emperor to minor and temporary London "notables," the process of attention to them remains in place, and the manner in which the publicity of these encounters so frequently overwhelms the quiet privacy of other moments is remarkably consistent. With only a slight anachronism, we might call these moments "celebrity sightings," and call their participants "celebrity seekers." In fact, what is increasingly at stake in the depiction of the famous in Thackeray's fiction

3 Bruce Robbins's reading of the anecdote is particularly compelling, as it concentrates on how Barlow's "imagination enjoys and amplifies the insatiable appetite and the evil intentions with regard to his own situation" (The Servant's Hand: English Fiction from Below [New York: Columbia Univ. Press, 1986], p. 106). 
is the gradual formation of a new category of public experience called the celebrity, unmoored from the political or aristocratic underpinnings of older forms of public notoriety and increasingly unlike earlier conceptualizations of fame. In the "celebrity," mid-Victorian culture found a social and perceptual category that could not only become more conceptually promiscuous - subsuming martial, literary, artistic, financial, governmental, and criminal fame into one form-but that could also root itself more deeply into the heretofore private consciousnesses of the public and, therefore, could reorient consciousness (particularly memory) toward a newly configured public realm.

Any study of celebrity in Victorian Britain must run along two axes: first, the institutions and practices that brought it into being; and second, the forms of consciousness that it produced. ${ }^{4}$ More than other mid-Victorian social satirists and observers, Thackeray comes into play as a figure whose addiction to and disdain for the emergent category of the celebrity is so palpable and readable that he furnishes us with several clues to the social and institutional origins of celebrity, as well as to a history of its alterations to cognition and memory. Much recent work on Thackeray has spotlighted the complex interactions between a public realm driven by market dynamics and a private realm struggling to maintain its independence; Janice Carlisle's study of Thackeray's relations with his audience, along with Andrew H. Miller's influential account of commodified consciousness in Vanity Fair $(1847-48)$, are two of the most compelling. ${ }^{5}$ Indeed, how nineteenth-century authors may

${ }^{4}$ Michael Warner has offered a similar, useful warning about reducing any analysis of a modern "public" to its institutions or specific manifestations: "the publicity of the public sphere never reduces to information, discussion, will formation, or any of the other scenarios by which the public sphere represents itself. The mediating rhetorical dimension of a public context must be built into each individual's relation to it, as a meaningful reference point against which something could be grasped as information, discussion, will formation" ("The Mass Public and the Mass Subject," in The Phantom Public Sphere, ed. Bruce Robbins [Minneapolis: Univ. of Minnesota Press, 1 993], p. 236).

${ }^{5}$ See Carlisle, The Sense of an Audience: Dickens, Thackeray, and George Eliot at MidCentury (Athens: Univ. of Georgia Press, 1981); and Miller, Novels behind Glass: Commodity Culture and Victorian Narrative (Cambridge: Cambridge Univ. Press, 1995), pp. 14-49. 
have been "spotlighted" themselves by increasingly sophisticated systems of publicity is a topic of growing interest, as authors whose public profiles may have seemed shadowy or obscure, from Henry James to Elizabeth Barrett Browning, are discussed through the public-sphere theories of Jürgen Habermas, Pierre Bourdieu, and Richard Sennett. ${ }^{6}$ Thackeray, more than most writers working within this public sphere, opens up for us the space where these relations between consciousness and publicity become most visible and most vexed: the celebrity. With the glimpse of Napoleon in his garden we enter a world in which what Leo Braudy has called the eighteenth century's "international European fame culture" metamorphoses into a culture of celebrity in which the grand figures of the past (Rousseau, Bonaparte, Byron) mix with a considerably more varied, and more constantly changing, group of figures. ${ }^{7}$ Suddenly the ceremonial, dramatic, and historically pivotal acts of the famous turn into the reciprocally ratifying, random encounter between celebrity and observer, each briefly entering the other's orbit and reanimating a deadened private world. Through an analysis of the collisions with celebrity in Thackeray's mid-career fiction, we might in fact encounter our own attitude toward celebrities in the age of its formation.

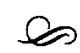

Many, if not most, of Thackeray's characters are animated or enlivened by life with the famous - they are celebrity seekers of more or less proficiency. Arthur Pendennis, for one, spends the days of his London youth breakfasting "with a Peer, a Bishop, a parliamentary orator, two blue ladies of fashion, a popular preacher, the author of the last new novel, and the very latest lion imported from Egypt or from

6 Two important recent examples include Richard Salmon, Henry James and the Culture of Publicity (Cambridge: Cambridge Univ. Press, 1997); and Linda M. Shires, "The Author as Spectacle and Commodity: Elizabeth Barrett Browning and Thomas Hardy," in Victorian Literature and the Victorian Visual Imagination, ed. Carol T. Christ and John O. Jordan (Berkeley and Los Angeles: Univ. of California Press, 1995), pp. 198-21 2.

7 See Braudy, The Frenzy of Renown: Fame and Its History (New York: Oxford Univ. Press, 1986), p. 371 . 
America," refreshing himself for his journalistic labor with a social set deliberately composed of the indiscriminately well known. ${ }^{8}$ Pen's casual acquaintances are no different, ranging from the Upper Temple law student Lowton, who introduces himself to Pen by pointing out "the notabilities in the Hall" (I, 295), to the pathetic Captain Sumph, "an ex-beau still about town, and related in some indistinct manner to Literature and the Peerage" (I, 338), whose dinner conversations consist primarily of anecdotes relating to his friendship with Byron and his time spent at Missolonghi. Charles Honeyman, the fashionable preacher of The Newcomes, is notable for nothing other than his proficiency at spotting the sort of minor celebrity known only to cognoscenti, while the best possible field for these activities is provided by Maria Newcome (Clive Newcome's aunt), whose parties are dedicated to in-the-know fame. Even Thackeray's characters situated outside the nineteenth century evince a similar passion: in The History of Henry Esmond ( 1852 ), besides the lengthier portraits of Marlborough, Steele, and Addison, there are smaller vignettes of encounters with Swift, Pope, Congreve, and others. Compared to equally sprawling social fictions by Dickens, Trollope, and George Eliot, Thackeray's world positively swarms with notables, major and minor, emergent and fading, as well as with the less famous who are nonetheless adept at noticing these figures at parties, in crowds, or on the street.

But are these figures "celebrities"? Or to ask a more precise question, when did the "figure" of celebrity emerge and take shape, and what other figural systems for classifying public fame competed with it? Some opening postulates are called for here. First, the word "celebrity" in its current meaning - a person of public fame - does not appear until the late 1840 , and Thackeray is among its first users..$^{9}$ In this usage Thackeray is

8 Thackeray, The History of Pendennis, ed. Peter L. Shillingsburg, 2 vols. in 1 (New York: Garland, 1991), I, 356. Further references are to this edition and appear in the text.

9 The $O E D$ lists 1849 as the first appearance of "celebrity" in its current guise, although the first attribution is not to Thackeray; he frequently used the word, however, in serial numbers of Pendennis that appear prior to the summer of 1849 . There are a number of suggestive studies of celebrity avant la lettre, particularly in the Romantic period: see Susan Wolfson, “The Mouth of Fame': Gender, Transgression, and Romantic Celebrity," in Essays on Transgressive Readings: Reading Over the Lines, ed. Georgia John- 
performing one of the analytic, and one might even say journalistic, tasks for which his intellect seemed most suited: discovering a new social category that had previously been invisible, and attaching to it a name whose immediate insertion into common use quickly elevates it from neologism to shorthand communication. "Snob," of course, is the most notable of these successes, and "bohemia" is similarly a Thackerayan term whose use has become so necessary that its coiner is almost entirely obscured. ${ }^{10}$ Even if "celebrity" is not precisely a Thackerayan coinage, it is nonetheless a term whose use Thackeray latched onto early in its history, and one that he found particularly congenial.

The second postulate is that the word "celebrity" in its early phase - the $185^{\text {os }}$ and 1860 - coexisted with a series of roughly similar terms whose usage overlapped. Although we can distinguish the nuances of "celebrity" from these cognate terms, we can also, in the process, establish the contours of this newer figure of fame in a fairly detailed manner. In getting to celebrity, that is, we need to take a detour through what celebrity is not.

The first "figure" of fame common to mid-Victorian discourse is the "notability" or the "notable," the figure of popularity. We might initially catch some of the sense of these terms by noticing that while none of Thackeray's major characters are celebrities, quite a few of them are notables, and many of them manage to achieve popularity. This popularity and notability, however, always resides within a circumscribed sphere-and that is precisely the important connotation of the "notable": notability and the public fame it offers remain limited to a particular circle, and since each circle has its own small set of no-

ston (Lewiston, N.Y.: Edwin Mellen, 1997), pp. 3-34; and Ghislane McDayter, "Conjuring Byron: Byromania, Literary Commodification and the Birth of Celebrity," in Byromania: Portraits of the Artist in Nineteenth- and Twentieth-Century Culture, ed. Frances Wilson (New York: St. Martin's Press, 1999), pp. 43-62. For an acute reading of Romantic celebrity memoirs written by women, see Catherine B. Burroughs, Closet Stages: Joanna Baillie and the Theater Theory of British Romantic Women Writers (Philadelphia: Univ. of Pennsylvania Press, 1997).

${ }^{10}$ For what is still the essential discussion of Thackeray's invention of "bohemia," see Eve Kosofsky Sedgwick, Epistemology of the Closet (Berkeley and Los Angeles: Univ. of California Press, 1990), pp. 193-95. 
tabilities, to be a "notable" is to subject oneself to a deeply relativistic sense of fame. To be popular, in other words, is always to be popular to some defined group. Pendennis achieves "popularity" within the confines of Oxbridge, a public fame so specific that Thackeray can define its limits with some precision:

Monsieur Pen at Oxbridge had his school, his faithful band of friends, and his rivals. When the young men heard at the haberdashers' shops that Mr. Pendennis, of Boniface, had just ordered a crimson satin cravat, you would see a couple of dozen crimson satin cravats in Main Street in the course of the week-and Simon, the Jeweller, was known to sell no less than two gross of Pendennis pins, from a pattern which the young gentleman had selected in his shop.

... Among the young ones Pen became famous and popular: not that he did much, but there was a general determination that he could do a great deal if he chose.

(I, 177, 179)

This is a precious enough fame, although Thackeray is at pains to note that the Oxbridge hierarchy would be entirely ignorant of it and that outside of the university its currency proves untransferable. Always in the wake of the notable is the ironic, and ironizing, awareness that every circle has its own. In 1863 the Scottish divine Patrick C. Beaton writes in Fraser's Magazine: "All courts have their notables . . . . All cities have their notables. London has its Lord Mayor, whom our French neighbours still persist in believing to be next in influence and authority to the Queen, and its court of aldermen, all of whom, doubtless, are notable men in their way. The literary, the scientific, the artistic, the religious, the fashionable world, all have their notables, not to mention many others of a nondescript character." 11 Thackeray himself wrote for Fraser's in the 1830 , and the journal had much to do with the formation of a Victorian celebrity discourse. But Beaton, contrary to any notion of celebrity, emphasizes the benumbing and belittling sense that all "notables" find their identical image in the smallest of their brethren. Thackeray echoes this idea in Pendennis: "A man may be famous in the Honour-lists and entirely unknown to the

11 [Patrick C. Beaton], "A Chapter on Notables," Fraser's Magazine, 67 (1863), 479. 
undergraduates: who elect kings and chieftains of their own, whom they admire and obey, as negro-gangs have private black sovereigns in their own body, to whom they pay an occult obedience, besides that which they publicly profess for their owners and drivers" (I, 179).

More august than notability, but no less problematic, is the fame of the "lion." "Common Lionism," Carlyle's well-known phrase uttered in the context of a description of the fate of Robert Burns, remains the term's touchstone; always with the lion, the quasi-celebrity, comes the question of lionizing - of how the ordinary is transformed into the known, as well as the savage and all-too-visible effects of that transformative process. Carlyle's description in On Heroes, Hero-Worship, and the Heroic in History (1841) of Burns's persecution by "Lion-hunters" contains one of the earliest usages of "celebrity," a term that for Carlyle will, like candlelight, "shew what man, not in the least make him a better or other man." ${ }^{12}$ Carlyle's passage is the originary source within mid-Victorian conversations on fame for the figure of the lion as the distorted, inflated, comically and frighteningly toothsome image of public notoriety. ${ }^{13}$

Thackeray was certainly familiar with this Carlylean usage: in "The Lion Huntress of Belgravia," one of his $185^{\circ}$ contributions to Punch, he presents the diary of a female hostess and devotée of fame: "They call me the Lion Huntress. I own that I love the society of the distinguished and the great. A mere cultivator of frivolous fashion, a mere toady of the great, I despise; but genius, but poetry, but talent, but scientific reputation, but humour, but eccentricity above all, I adore." 14 She adds: "Indeed what is there in life worth living for but the enjoyment of the society of men of talent and celebrity?" (p. 325). The incoherent categorical mixtures of celebrity are here, but one remains aware in Thackeray's sketch that the hostess is not

12 On Heroes, Hero-Worship, and the Heroic in History, ed. Michael K. Goldberg, Joel J. Brattin, and Mark Engel (Berkeley and Los Angeles: Univ. of California Press, 1993), p. 166.

${ }^{13}$ For the links between Thackerayan narrative and Carlyle's "heroes," see Ian Ousby, "Carlyle, Thackeray, and Victorian Heroism," The Yearbook of English Studies, 12 (1982), $15^{2-68 .}$

14 Thackeray, "The Lion Huntress of Belgravia," in Works, XxxI, 324. 
merely entertaining the famous but also creating them; not merely hunting lions but also making them. And if lionizing is a potentially fatal process, as Carlyle contended had been the case with Burns, then the lion itself is dangerous: as Thackeray's Belgravian hostess says, "it gives one a sort of thrill" to have in one's home a lion "who has hanged twenty-five Polish Colonels, like Count Knoutoff; or shot a couple of hundred Carlist officers before breakfast, like General Garbanzos, than whom I never met a more mild, accomplished, and elegant man" (p. 331). For Victorian commentators the indiscriminacy of lionizing, combined with the sudden glare of attention that the "lion" figured, produced an image of the terrors of the transformative processes of publicity, a fear that this sort of fame was not tameable.

Neither the notable nor the lion is quite a celebrity; sharing a certain overlapping territory but contributing quite different nuances, these terms teach us largely what preexisted celebrity in the decades of its emergence. A look at one of the initial entrances into English of the "celebrity" is illuminating. In The Newcomes Charles Honeyman, interpreting for Colonel Newcome a room of Maria Newcome's invited celebrities, says:

"Let me whisper to you that your kinswoman is rather a searcher after what we call here notabilities. ... That is Mr. Huff, the political economist, talking with Mr. Macduff, the member for Glenlivat. That is the Coroner for Middlesex conversing with the great surgeon Sir Cutler Sharp, and that pretty little laughing girl talking with them is no other than the celebrated Miss Pinnifer, whose novel of Ralph the Resurrectionist created such a sensation after it was abused in the Trimestrial Review. It was a little bold certainly-I just looked at it at my club-after hours devoted to parish duty a clergyman is sometimes allowed, you know, desipere in loco-there are descriptions in it certainly startlingideas about marriage not exactly orthodox-but the poor child wrote the book actually in the nursery, and all England was ringing with it before Dr. Pinnifer, her father, knew who was the author. That is the Doctor asleep in the corner by Miss Rudge, the American authoress, who I daresay is explaining to him the difference between the two Governments. My dear Mrs. Newcome, I am giving my brother-in-law a little sketch of some of the ce- 
lebrities who are crowding your salon to-night. What a delightful evening you have given us!" 15

Alongside all these "notabilities" we find "a young barrister, already becoming celebrated as a contributor to some of our principal reviews," as well as "Professor Quartz and Baron Hammerstein, celebrated geologists from Germany," and an unnamed cavalry officer who is a "literary man of celebrity, and by profession an attorney" (I, 74). And although Honeyman selfconsciously terms these men "notabilities," the newer word "celebrity" begins to dominate the passage, in one of the first uses of the word in English as a substantive noun. Honeyman's knowingness here is clearly satirized, and yet it just as clearly marks him out for the kind of narratorial snobophobia that, as Joseph Litvak has argued of Thackeray, masks an equivalent homophobia. ${ }^{16}$ But while Honeyman is so obviously a celebrityseeker of the most parasitical sort, that is no reason why his knowledge - the knowingness about the various demi-mondes of London that he flaunts so readily - is invalid: the idea that a fashionable preacher should be so well informed about such medical, political, and literary celebrities argues well enough for their status as celebrities, no longer confined to the narrow circles of influence and regard that distinguish, and in turn extinguish, the merely "notable."

Further, there is no danger to, or from, these "lions," save the merely feline dangers of a certain catty gossip passed from guest to guest-no threatened demise at the hands of lionhunters, no fear that these lions pose any ethical or even criminal questions. Unlike Napoleon, these lions do not threaten to eat sheep-and thus "lion," with its connotations of distortion and danger, is the incorrect term. Mrs. Newcome does not so much lionize these figures - that is, create their fameas participate in their aura as celebrities, as figures meant to

15 Thackeray, The Newcomes: Memoirs of a Most Respectable Family, ed. Peter L. Shillingsburg, 2 vols. in 1 (Ann Arbor: Univ. of Michigan Press, 1996), I, 75.

16 See Strange Gourmets: Sophistication, Theory, and the Novel (Durham, N.C.: Duke Univ. Press, 1997), p. $5^{6 .}$ 
be observed, brushed up against, talked about, and above all recognized.

Celebrity is a term that is absolute (in contrast to the relativism of popularity) and expressive of a certain passiveness (as opposed to the active quality of "lionizing"). Someone who is a celebrity to one person or group is, within a mass culture, a celebrity to all, and even if the mark of celebrity has been lowered from Napoleon to teenage authors of scandalous novels, that is no reason why the celebrity of the latter cannot eventually equal the celebrity of the former-a principle that Thackeray divined and that has been amply borne out in our own time. Once one becomes a celebrity, from whatever field, then one's membership in that field is less relevant than one's status as celebrity, no longer a "notable among the undergraduates" but a notability proper, a celebrity above all else. The very erratic and catholic mixture of guests at Mrs. Newcome's home is a vision of a culture of celebrity in which institutional boundaries mean little except for the overarching institution - the daily and periodical press - that licenses them all and from which, presumably, Honeyman has gathered much of his insider's information. Those who most misunderstand celebrity in Thackeray's fiction, such as Major Pendennis, do so not from a failure to read the newspaper (itself inconceivable in Thackeray's world) but from a failure to read it well and thoroughly - a failure that usually involves concentrating solely on the aristocratic world and its movements. Mrs. Newcome, for one, is past that particular boundary: "Dr. Windus is a man of science and his name is of European celebrity!" she responds to her husband when he complains of her dull guests; "Any intellectual person would prefer such company to the titled nobodies into whose family your brother has married" (The Newcomes, I, 152).

In an analogous manner, what had been the active process of lionizing - lion-hunters descending upon Carlyle's great or the nation's talentless in an indiscriminate pack, looking to transform - can only be understood in Thackeray's writing as an entirely mysterious process of celebrity-construction, and only articulated in passive phrases. Thus the force of the original locution of celebrity - "celebrated as" - makes us ask: cele- 
brated by whom? Honeyman's syntax ("A young barrister already becoming celebrated") precludes an answer: the process has already started, and wherever it takes place, it does not take place here, exactly, but always somewhere else, always with reference to a phantasmatic other who has initiated the distinction that we only recognize. ${ }^{17}$ The knowingness that defines Honeyman, and that, in another temperament, might expose these "celebrities" as frauds, is yet powerless to explain how the mysteries of celebrity have originated.

The theoretical term that does much of the work of "celebrity," although in a less awestruck fashion, is charisma, as first articulated by Max Weber and later developed by Pierre Bourdieu. "Charm and charisma," Bourdieu writes, "in fact designate the power, which certain people have, to impose their own self-image as the objective and collective image of their body and being; to persuade others, as in love or faith, to abdicate their generic power of objectification and delegate it to the person who should be its object, who thereby becomes an absolute subject, without an exterior (being his own Other), fully justified in existing, legitimated." 18 In opposition to the lionhunter's objectifying, which denies the true greatness (or true poverty) of the hunted by the process of a violent adulatory caricature, charisma is the celebrity's defense against being objectified, a seigneurial right to objectify the other as Observer, as Fan. And as Weber perceived, the sign of charisma is a freely given "recognition" on the part of the observer, one that legitimates the charismatic leader but also, paradoxically and yet necessarily, legitimates the recognizer. ${ }^{19}$ The social history of the nineteenth century is remarkably full of vivid instances of charismatic authority, particularly in the arts, from which the

17 Michael Warner has termed this process "the moment of special imaginary reference" ("Mass Public," p. 236).

18 Pierre Bourdieu,Distinction: A Social Critique of the Judgement of Taste, trans. Richard Nice (Cambridge, Mass.: Harvard Univ. Press, 1984), p. 208.

19 "It is recognition on the part of those subject to authority which is decisive for the validity of charisma. This is freely given and guaranteed by what is held to be a 'sign' or proof, originally always a miracle, and consists in devotion to the corresponding revelation, hero worship, or absolute trust in the leader" (Max Weber, The Theory of Social and Economic Organization, ed. Talcott Parsons, trans. A. M. Henderson and Talcott Parsons [New York: Free Press, 1947], p. 359). 
relevant instances of the performances of Rachel, or of Paganini, might be adduced.$^{20}$ If we need to make any readjustment to Weberian charisma in order to match it to mid-Victorian "celebrity," however, it is to remove from Weber's term any sense of its necessary linkage to talent, efficacy, or lastingness. As Leo Braudy puts it in The Frenzy of Renown, the early nineteenth century learned how "success could easily be confused with visibility, celebrity with fame"; but the recognition of the ephemerality, or delusiveness, of celebrity was never an effective critique against its power (p. 425). Concerning Mr. Wagg, one of a host of writers populating Pendennis, Pen may laugh at what is called "Mr. Wagg's celebrity" and say that "he is a dunce, and that any body could write his books" (I, 253), but this assertion hardly injures Wagg's status, which might feed equally well on denunciations as on praise. As a variety of fame, celebrity was from the start both inured to the criticisms that might see through its hollowness and resistant to the ephemerality that often defined its essence.

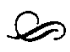

Joshua Reynolds's famous painting Garrick between Tragedy and Comedy (1762) formed the basis for Thackeray's ironically allusive cover drawings for Pendennis's serial and book publications - a more or less leering Pen tugged at by a nude blonde siren on one side and a maternal brunette on the other. Thus, the painting has always offered an excellent imagistic basis from which to discuss Thackeray's continual ambivalences, his characteristic inability to decide between what might seem like oppositional alternatives. ${ }^{21}$ Similarly, the char-

${ }^{20}$ For Rachel, see Rachel M. Brownstein, Tragic Muse: Rachel of the Comédie-Française (New York: Alfred A. Knopf, 1993); for Paganini, see Richard Sennett, The Fall of Public Man (New York: W. W. Norton, 1977), pp. 200-203; and for an examination of the symphony conductor as an image for a certain, scientized version of charismatic power, see Alison Winter, Mesmerized: Powers of Mind in Victorian Britain (Chicago: Univ. of Chicago Press, 1998), pp. 310-1 2.

${ }^{21}$ Martin Meisel has provided a compelling reading of Reynolds's painting as an allegory for Thackeray's ambivalence toward his position as both artist and marketable performer: "For Thackeray, the honor of the artist and the honor of the public performer are two faces of one situation-his own. One face, however, like Reynolds' 
acteristic of Thackeray's writing that appears most marked in his relations to Victorian celebrity is the fierce quality with which he upholds strongly different attitudes toward it. At once resenting the floodlit, falsely intimate publicity it brings and yet seeking to penetrate any barriers of privacy that might screen out the light, Thackeray offers us as well a paradigmatic example of the dual, even dialectical, relations that Victorian massculture increasingly held toward the celebrities it began to produce. The first of the two oscillating relations that Thackeray illuminates for us involves privacy and publicity; the second involves distortion, monstrosity, and caricature. For the sake of taxonomical convenience I will term the first relation the "dynamic of publicity" and the second the "dynamic of monstrosity"; as we will see, however, both of these processes are instances of a larger fact about Victorian celebrity-formation: it involved a continual shuttling between mutually antithetical concepts. $^{22}$

The "dynamic of publicity" is the gesture of both protesting against the invasions of privacy to which the celebrity is subjected and yet performing those very invasions in the service of puncturing the aura of the given celebrity, thereby demonstrating a knowingness that might discern true celebrity from both

Tragedy, speaks from the vantage of superiority. It enjoins a respect for the integrity and honesty of the work, and a qualitative standard quite apart from fashion and the market. The other face acts from the disadvantage of dependence. It requires a success that entails cajoling an audience subject to fashion and providing the market, though the performer cannot afford to seem willing to go to any lengths for popularity" (Realizations: Narrative, Pictorial, and Theatrical Arts in Nineteenth-Century England [Princeton: Princeton Univ. Press, 1983], p. 347). Meisel's reading of Thackeray's dual relationship to his craft bears a strong relation to my reading of Thackeray's deeply ambivalent relation to his sudden celebrity as well as his culture's sudden embrace of "celebrity." For complementary readings of Thackeray's habitual ambivalences, see Miller's analysis of a "dynamic of desire and disenchantment" (Novels behind Glass, p. 22); and for a reading of Thackeray's syntactical, and conceptual, collapse of antithetical concepts, see Elaine Scarry, "Enemy and Father: Comic Equilibrium in Number Fourteen of Vanity Fair," Journal of Narrative Technique, 10 (1980), 145-55.

${ }^{22}$ This "dynamic shuttling" might not be solely a property of Victorian celebrity discourse; Michael Warner has analyzed the modern "double movement of identification and alienation" characteristic of contemporary response to public icons ("Mass Public," p. 252). Of additional interest is Jacqueline Rose's recent account of celebrity, in which the paradoxes it encapsulates are read as examples of perversion or even sadism (see "The Cult of Celebrity," New Formations, no. 36 [1999], 9-20). 
false, mindless fandom and from accurate estimations of worth. It is not entirely surprising, of course, that the same public that so eagerly consumes information on the private life of the famous might also inveigh most heavily against the methods used to gather that information. What is perhaps more striking is that, rather than an aberration, the dynamic of publicity might be an essential characteristic of a mass public's response to celebrity.

Indeed, the most well-known facts about Thackeray's own dealings with publicity bear out this idea. One example is the famous "Garrick Club Affair" of 1858 , in which Thackeray went to extremes to punish Edmund Yates, the writer of a particularly vicious and personal critique of Thackeray in Town Talk, for Yates's invasion of the cordon sanitaire of the gentleman's club. And an earlier example is Thackeray's impulsive resignation from Punch in $185^{1}$ over the publication of a starkly critical cartoon depicting Napoleon III as "A Beggar on Horseback," complete with bloody sword, liquor flask, and dead bodies. ${ }^{23}$ In both of these instances Thackeray expended personal and career capital to defend a certain sanctity and dignity of public life from invasions of an increasingly aggressive press. Many of his sketches were written to the same effect, particularly when the target was the gentleman's club and its inhabitants. In "Strange to Say, on Club Paper'” (1863), from the Roundabout Papers, Thackeray complains at length about an obituary of Field-Marshal Lord Clyde, published in the $O b$ server, in which the writer notices that a codicil from Clyde's will, signed at Chatham, has been written on the paper of the Athenæum Club - with the obvious implication that the rich and respected Clyde was in the habit of stealing paper from his club and carrying it with him to the country. The all-seeing eye of the press has seized upon a detail, Thackeray wants us to notice, and has used that ambiguous detail of private habits to impugn a public figure, subtly and without overt claims.

23 Both Peter L. Shillingsburg and Gordon N. Ray provide detailed accounts of the resignation and how Thackeray handled his indignation over the caricatures; see Shillingsburg, Pegasus in Harness: Victorian Publishing and W. M. Thackeray (Charlottesville: Univ. Press of Virginia, 1992), pp. 8o-84; and Ray, Thackeray: The Age of Wisdom, I 847I 863 (New York: McGraw-Hill, 1958), p. 172. 
The true explanation for the codicil, Thackeray argues, is that Clyde's lawyer wrote it at the Athenæum and sent it to Chatham for Clyde's signature. Yet in Thackeray's view the falseness of the implied accusation is only a symptom of the real problem, which for him amounts to a systemic reportorial invasion of the smallest facts of private existence. Imagining himself as a latter-day Jeremiah sent to alert his fellow clubmembers, Thackeray envisions stationing himself as an outdoor "Pall Mall preacher" to deliver his public lecture on the evils of the press. But he chooses a curious location for this fantasy: "I would have taken post under the statue of Fame, say, where she stands distributing wreaths to the three Crimean Guardsman." ${ }^{24}$ In other words, Thackeray is not only defending privacy but fame itself, which is under attack from the deflations of the press; a more ancient concept of fame, depending on martial valor (Clyde's courage, the sacrifice of Crimean soldiers) must be protected from the depredations of mass publicity.

However much the Clyde incident may have obtained in Thackeray's thinking about real-life public figures, within his fiction Thackeray presents the private failings of a variety of public figures (many of them military), subjecting them to a critique that has often enraged his readers. The Marlborough of Henry Esmond is duplicitous and endlessly greedy for power; when Thackeray has Addison say that "we must paint our great Duke ... not as a man, which no doubt he is, with weaknesses like the rest of us, but as a hero," Esmond responds with a severe argument against this sort of distorted panegyric in favor of a more intimate picture of Marlborough's flaws. ${ }^{25}$ So constant is this process in Thackeray's historical fiction that it forms the centerpiece of Georg Lukács's seminal attack on Thackeray's "distortion of history, its degradation to the level of the trivial and the private." ${ }^{26}$ Steele is a genial drunk, Addison a phlegmatic courtier, Swift a choleric panderer to power - traits that obtain not only within Henry Esmond but also within Thack-

${ }^{24}$ Thackeray, “'Strange to Say, on Club Paper,'” in Works, xxviI, 413-14.

25 Thackeray, The History of Henry Esmond, ed. Edgar F. Harden (New York: Garland, $1989)$, p. 212.

${ }^{26}$ See The Historical Novel, trans. Hannah and Stanley Mitchell (London: Merlin Press, 1962), p. 204. 
eray's lectures on The Four Georges and The English Humourists $\left(185^{1}\right)$, where we are invited to ask of a public figure, as Thackeray asks of Swift, "Would we have liked to live with him?" 27

Beyond these facts we have the early Thackeray of Fraser's Magazine, the journal that under the proprietorship of William Maginn was perhaps most notable among Victorian periodicals for propagating a journalism dependent upon a mockrespectful attitude toward cultural nobilities, one that poked sophisticated fun at the figures whose exposure in the journal made it alluring. In 1836 Maginn - usually noted as the model for Captain Shandon in Pendennis, who runs the very Fraserian Pall Mall Gazette-originated a series of pictorial and verbal portraits of the newly notable entitled "The Gallery of Literary Characters," which included sketches of Sir John Soane and Michael Faraday, among others. The tone of the sketches is instructive, combining an "insider's knowledge" of the figure with an elaborately mock-panegyric style that is subtle enough to be read as simple praise: it is a deflation couched as a celebration, one in which the celebration invites the readers and the deflation allows them access to a knowingness that at once acknowledges and ridicules the power of the minor celebrity in question. ${ }^{28}$ Of course, Thackeray himself was well acquainted with the journalistic machinery so often used to invade the sacrosanct privacy of public figures, and he was as adept at making those invasions as he was at protesting them. Thackeray's story "Ravenswing," which was published in Fraser's in 1843, is noth-

27 Thackeray, The English Humourists of the Eighteenth Century, in Works, XXvI, 153 .

28 Fraser's was not the only journal, of course, beginning a discourse of celebrity. One other relevant example was Bentley's Miscellany, which under the proprietorship of W. H. Ainsworth issued a study of "American Notabilities" in November 1861 -including Lincoln, Jefferson Davis, and George McClellan - and the more ironical "Parisian Notabilities" in October 1864, in which figures from Napoleon III to the feuilletoniste Vicomte Ponson du Terrail were simultaneously "celebrated" and derided (see "American Notabilities: Lincoln-Jeff Davis-Stephens-Fremont-Beauregard-M'Clellan -Banks," Bentley's Miscellany, 50 [1861], 456-64; and "Parisian Notabilities," Bentley's Miscellany, $5^{6}$ [1864], 343-55). The procedure of these journals is best summarized by Flaubert, whose definition of "celebrity" ran as follows: "S'inquiéter du moindre détail de leur vie intime afin de pouvoir les dénigrer [Look into the smallest details of their private lives so that you can disparage them]" (Flaubert, Le Dictionnaire des idées reçues; et, Le Catalogue des idées chic, ed. Anne Herschberg Pierrot [Paris: Librairie Générale Française, 1997], p. 57; my translation). 
ing less than an acute and detailed depiction of the creation of an operatic celebrity through a skilled manipulation of advance publicity. The story's narrator, very much in tune with the tone that Fraser's maintained, takes pleasure in describing the creation of what now goes under the name of "buzz," one that all but drowns out the sound of the eponymous character's admittedly mediocre singing.

The game of knowingness that Fraser's made so attractive, and that is such a strong part of Thackeray's depiction of celebrity, remains central to an understanding of the second dynamic in play in Victorian celebrity-formation. The "dynamic of monstrosity" may be summarized as the dual gesture of enlarging the image of the celebrity in question, combined with the pleasure of puncturing this enlarged image. Inflation and deflation, in a continual combination, comprise the game of celebrity in Thackeray's fiction, where the great are routinely built up out of the small in order to be forcibly returned back to the small. Much of the work of celebrity in Thackeray's writings might be called the work of "debunking," such as this moment from The Newcomes when Pendennis, George Warrington, the Reverend Honeyman, and Clive Newcome sit around a dinner table astonishing the older Colonel Newcome with their inthe-know deflations of the famous:

He heard opinions that amazed and bewildered him. He heard that Byron was no great poet, though a very clever man. He heard that there had been a wicked persecution against Mr. Pope's memory and fame, and that it was time to reinstate him: that his favourite, Dr. Johnson, talked admirably, but did not write English: that young Keats was a genius to be estimated in future days with young Raphael: and that a young gentleman of Cambridge who had lately published two volumes of verses, might take rank with the greatest poets of all. (I, 195)

The shocked Colonel responds that the young men "will be sneering at Shakspeare next"-a comment that does not prevent them from progressing to pictorial art, where they debunk Haydon and canonize Turner.

This scene is not only (or not merely) a representative pic- 
ture of changing tastes in the mid-1830s: it is more crucially a moment where an entirely new attitude toward fame begins to reveal itself, one in which debunking and deifying go hand in hand and in which the very unusual quality of one's judgment, a sort of novelty for novelty's sake, becomes prized. It is, in short, the discourse of fame-as-celebrity, where a more or less fixed canon of the famous is replaced by the quick, capricious, and always-subject-to-revision judgments of a "knowing class" - here composed of two journalists, an artist, and a clergyman - that engages itself in the pleasures of smart praise and even smarter critique. We might be reminded here of Thackeray's own brush with extreme literary fame: his brief meeting with Goethe during a youthful stay in Weimar in 1831. In an 1855 letter to G. H. Lewes, Thackeray records both his awe at the great man and a gleefully satirical comment about him: "I recollect I was at first astonished, and then somewhat relieved, when I found he spoke French with not a good accent." ${ }^{29}$ This is also a world in which all publicity is good publicity; in The Newcomes Fred Bayham relates how, in an effort to help out Charles Honeyman and attract crowds to his sermons, he writes savage reviews of these sermons in the Pall Mall Gazette: "I wrote an article of controversial biography in the P.M.G., set the business going in the daily press; and the thing was done, Sir" (II, 55 ). This is the incipient world of the "star"-and it is no accident that one of the first usages of this word in its current range of meaning is in Pendennis, where Warrington puffs Pen's book to the publisher Bacon by proclaiming, "I tell you he's a star; he'll make a name, sir. He's a new man, sir" (I, 317).

But why is it a dynamic of "monstrosity"? Why term the inflation and deflation of the celebrity as "monstrous"? To answer this question, it is instructive to return to Thackeray's childhood sighting of Napoleon, the savage sheep-eater of his servant's imagination, as well as to his anger at the caricature of Napoleon III in Punch: in both cases we have an enlargement

29 Thackeray, letter to G. H. Lewes, 28 April 1855 , in The Letters and Private Papers of William Makepeace Thackeray, ed. Gordon N. Ray, 4 vols. (Cambridge, Mass.: Harvard Univ. Press, 1945-46), III, 444. The letter is also printed separately as "Goethe in His Old Age," in Works, xxx, $45^{2-5} 6$. 
and distortion of the image (usually the body-image) of the public figure that creates something disturbing and uncategorizable - a monster. ${ }^{30}$ It is well established that Thackeray found himself literally and figuratively enlarged in the years of what Gordon N. Ray calls his "rise to celebrity" (Age of Wisdom, p. 35), and that this enlargement left him open to a variety of puncturing critiques, such as Yates's article in Town Talk. In Thackeray's work the celebrity has a linkage to something powerful and unsettling at once, something that calls for immediate deflation; thus the frequent combination in Thackeray's prose of locutions of "celebrity" and locutions of infamy, such as his introduction in the 1862 sketch "Dessein's" of "the notorious, nay, celebrated Mr. Laurence Sterne." 31 The dual gesture here is at every moment canceling itself out: to call Sterne a celebrity, to "celebrate" him, involves a concomitant gesture of pointing to his unsavory "notoriety," which hardly invalidatesindeed might even enhance-his celebrity status. To praise is not necessarily to avoid puncturing, and to puncture is not necessarily to impair the quality or intensity of celebrity.

Thus, the dynamics of celebrity in Thackeray's writing, whereby the celebrity is at once exalted and punctured, and whereby the machinery of publicity that creates celebrities is at once targeted as an ill and exploited as a tool, are systematically conflicted. These are social attitudes and processes, as is evident from the sorts of milieux in which they are situated in Thackeray's work: at dinner tables, before Pall Mall clubs, in open and even litigious contestation with enemies, and in public acts such as resignations, reviews, and profiles. But however much one ties the processes and shapes of celebrity to public institutions such as the periodical press or public moments

${ }^{30}$ Bourdieu's analysis of the manner in which caricature- one of Thackeray's talents - relates to the enlargement of the image of the charismatic figure is useful here: "It would seem that the logic whereby the 'great' are perceived as physically greater than they are applies very generally, and that authority of whatever sort contains a power of seduction which it would be naive to reduce to the effect of self-interested servility. That is why political contestation has always made use of caricature, a distortion of the bodily image intended to break the charm and hold up to ridicule one of the principles of the effect of authority imposition" (Distinction, p. 208).

31 Thackeray, "Dessein's," in Works, xxviI, 348. 
such as dinner conversations and published evaluations, there remains a stratum of analysis left untouched - the very structuring of consciousness that a sphere of celebrity might create. To this end, it is necessary to return to one particular genre of Thackerayan celebrity, one whose very frequency testifies to its hold upon mental, and particularly mnemonic, habits: the casual brush with fame.

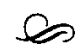

On Clive Newcome's first trip to Paris, his host, the Vicomte de Florac, directs his attention not to architectural features but to Parisian celebrities: "He pointed out to us no end of famous people at the opera-a few of the Fauxbourg St. Germain, and ever so many of the present people:M. Thiers, and Count Molé, and Georges Sand, and Victor Hugo, and Jules Janin - I forget half their names" (The Newcomes, I, 204). These are "present people" indeed, who put the feudalized notables of St. Germain into the shade and who make Clive feel more than ever "present" himself, both in the sense of up-to-date and, crucially, in place, in a recognizable and defined space that is legitimated by the celebrities who inhabit it. Politicians, writers, and critics define this sphere, which not coincidentally gathers in a theater, where-if the first form of modern celebrity comes from the stage and its "stars," such as the tragedian Rachel-the glare of celebrity has switched from the footlights to the audience itself. Thackeray's major characters continually orient themselves, and understand the significance of their new locales, through casual sightings of the famous. Arthur Pendennis, upon first arriving in London, meets with a reporter for the Star, who shows him a minor celebrity: "As they passed by Brompton, this gentleman pointed out to Pen Mr. Hurtle, the reviewer, walking with his umbrella. Pen craned over the coach to have a long look at the great Hurtle. . . Pen thought it was quite an honour to have seen the great Mr. Hurtle, whose works he admired" (I, 280). However satirical the portrait of Pen's celebrity-hunting ishowever minor a celebrity this Hurtle might be-Pen's reaction 
is so thoroughly consistent with the reactions of other Thackeray characters meeting with more august fame (such as Clive meeting Victor Hugo, or Esmond meeting Swift and Congreve) that it deserves a closer look. What we have here, in fact, is a small example of a structure of consciousness that for Thackeray is often routed through the fame of celebrity: a fantasized intimacy that colors these scenes, a memory that organizes itself through encounters with fame, and finally a mass consciousness whose sameness is guaranteed by the mass fame that any of us might, for a time, glimpse.

The false, or phantasmatic, intimacy of celebrity is revealed in the effect of that key detail of Mr. Hurtle's appearance, his umbrella. In itself absolutely innocuous, this slight addition to the encounter, the one detail of Hurtle's appearance caught by Pen, not only humanizes "the great Hurtle" but also provides the central fantasy of all of Thackeray's presentations of the famous: they might always be caught in the act of humanizing themselves, whether through the sort of foibles that Lukács deplored or through the irrelevant, but suddenly totemic, detail that makes the celebrity seem closer to us. Even the famous, we learn with relief, try to avoid getting wet. This is not solely a gesture of deflation - catching the great in the act of being ordinary - but also an act of imaginative identification, whereby the great are revealed as fantasized intimates without losing their aura of fame; to learn that Hurtle carries an umbrella, or that Steele drinks to excess, is not to rob them of their celebrity but merely to add to it a leering, and yearning, knowledge that even the celebrity can act like us. This is of course often a moment for Thackeray to parody the pretend intimates of the famous: in Pendennis Captain Shandon of the Pall Mall Gazette, even while in debtor's prison, "spoke of the characters of the day, and great personages of the fashion, with easy familiarity and jocular allusions, as if it was his habit to live amongst them. He told anecdotes of their private life, and of conversations he had, and entertainments at which he had been present, and at which such and such a thing had occurred. Pen was amused to hear the shabby prisoner in a tattered dressing-gown talking glibly about the great of the land" (I, 324). But this ridiculous 
affectation of pretending to intimacy with celebrities is by no means restricted to Shandon; in fact, it constitutes a general response to the famous: the establishment of a "familiarity" that is as pathetically phantasmatic as it is common. ${ }^{32}$

Yet the consciousness of celebrity depicted by Thackeray does not stop with a "fan" yearning for intimacy with his chosen object, for a casual encounter with the famous organizes a series of facts about biography, memory, and witnessing-in short, it gives shape to a life. Here is Pendennis and his uncle bumping into one of the early nineteenth century's pinnacles of fame, the Duke of Wellington:

Master Pen was not displeased to accompany his illustrious relative, who pointed out a dozen great men in their brief transit through St. James's Street, and got bows from a Duke at a crossing, a Bishop (on a cob), and a Cabinet Minister with an umbrella. The Duke gave the elder Pendennis a finger of a pipe-clayed glove to shake, which the Major embraced with great veneration; and all Pen's blood tingled, as he found himself in actual communication, as it were, with this famous man, (for Pen had possession of the Major's left arm, whilst that gentleman's other wing was engaged with his Grace's right,) and he wished all Grey Friars' School, all Oxbridge University, all Paternoster Row and the Temple, and Laura and his mother at Fairoaks, could be standing on each side of the street, to see the meeting between him and his uncle, and the most famous duke in Christendom.

Almost literally electric, the celebrity's energy is conducted from the proffered finger, through the Major's right arm, to the left arm that Pen holds; here Pen's fantasy is of a collective witnessing of the event, a collectivity that in fact summarizes his own life at that moment, from school to university to occupa-

${ }^{32}$ It is interesting to note, when thinking of the fantasized familiarity with the great that Thackeray's characters so often possess, that Thackeray's own prose style was critiqued by Trollope-otherwise Thackeray's greatest admirer-for what Trollope called its "affected familiarity": "He indulges too frequently in little confidences with individual readers, in which pretended allusions to himself are frequent" (Anthony Trollope, Thackeray [London: Macmillan, 1879], p. 201). 
tion and back to "home." ${ }^{33}$ As much as the event encapsulates an embodied fantasy of intimacy - and we should note as well the Cabinet Minster's umbrella, a recurrent trope of Thackeray's - it also helps to bring all of Pen's life into focus, condensed by the meeting with a celebrity.

The brush with fame in Thackeray's writings provides a node of memory onto which other, more merely biographical, facts can hang and around which they can cohere. As surely as the moment before death is supposed to permit one's life to flash before one's eyes, the glare of the celebrity's light puts one's own life into relief. Continually in Thackeray's sketches and longer fictions his narrators and characters recall pivotal moments of private biography through their coalescence with public facts about the famous. For Thackeray himself those facts were often organized around the famous of his youth, including George IV; for instance, in "De Juventute" (1860), from the Roundabout Papers, Thackeray affirms that simply by staring at a coin with George IV's image on it, a person can "conjure back his life there"; and in "On a Peal of Bells" ( 1862) he recalls a day from youth because it was the day his sovereign was crowned. ${ }^{34}$

This phenomenon is an early account of what psychological theorists and neuroscientists today term "flashbulb memories": strongly vivid recollections of private facts insofar as those facts combine with a moment of public trauma; the sort of memory licensed, and in fact culturally validated, by the question "where were you when you heard that President Kennedy was shot? ${ }^{35}$ Where were you, Thackeray asks, when you heard

${ }^{33}$ I owe the term "collective witnessing" to Michael Warner, who discusses it in relation to one of the salient facts of modern mass consumption, in which "our desires have become recognizable through their display in the media; and in the moment of wanting them, we imagine a collective consumer witnessing our wants and choices. The public discourse of the mass media has increasingly come to rely on the intimacy of this collective witnessing in its rhetorics of publicity, iconic and consumerist alike" ("Mass Public," p. 242).

34 See Thackeray, "De Juventute," and "On a Peal of Bells," in Works, xxviI, 8o, 322.

35 See Daniel L. Schacter, Searchingfor Memory: The Brain, the Mind, and the Past (New York: Basic Books, 1996), pp. 195-201, for a lucid summary of recent research into what constitutes "flashbulb memories," a summary that in fact employs the "when Kennedy was shot" example as central. If there is anything missing from this account, as from research on the topic in general, it is a more theoretical consideration of what in 
that George IV was crowned? Increasingly in Thackeray's work the private facts of memory are only accessible by reference to what some public figure, caught in a flashbulb of fame, was doing at the time, or how that public figure, the nascent celebrity, intersected with one's own life.

The lengthy, and often-cited, sketch "On Some Carp at Sans Souci" (1863) is especially relevant here. In this sketch Thackeray imagines an encounter with a ninety-year-old inmate of a workhouse, who cannot herself recall any salient biographical facts; indeed she need not, because Thackeray can remember them for her - with reference, of course, to the famous that Grandmother Goody Twoshoes has encountered:

My good old creature, you can't of course remember, but that little gentleman for whom your mother was laundress in the Temple was the ingenious Mr. Goldsmith, author of a "History of England," the "Vicar of Wakefield," and many diverting pieces. . . . That gentleman who well-nigh smothered you by sitting down on you as you lay in a chair asleep was the learned Mr. S. Johnson, whose history of "Rasselas" you have never read, my poor soul .... That tipsy Scotch gentleman who used to come to the chambers sometimes, and at whom everybody laughed, wrote a more amusing book than any of the scholars, your Mr. Burke and your Mr. Johnson, and your Doctor Goldsmith. Your father often took him home in a chair to his lodgings; and has done as much for Parson Sterne in Bond Street, the famous wit. . . With the help of a "Wade's Chronology," I can make out ever so queer a history for you, my poor old body, and a pedigree as authentic as many in the peerage-books. ${ }^{36}$

The biography that Thackeray sketches here is fantastic, but that is no argument against its plausibility. Thackeray's underlying claim is that our distinctiveness - that is, what makes us stand out, even among classes distant from celebrity-relies upon the very real chance that we have met, seen, touched, or known a famous individual. The paradox, of course, is that this

modern mass culture might be so effective at tying personal recollection to public, and in fact celebritized (thus the "flashbulb"), events.

36 Thackeray, "On Some Carp at Sans Souci," in Works, xxvII, $362-63$. 
very uniqueness also makes our memories identical to everyone else's - the consequence of a mass memory based on public figures. Thackeray invents a plausible, if unverifiable, biography for old Goody based on a chronology of public events, which only reduces her uniqueness by the very extent to which it provides us with any detail at all. The memory that is organized through brushes with fame is, as Thackeray shows us, a memory that is all the more a property of a mass public, and therefore all the more susceptible to being shaped by mass publicity.

For those who have noted and despaired at this condition of modern memory-its strange reliance upon the managed character of modern public celebrity - the hoped-for revenge is usually that the celebrity will have a shorter than usual shelf life. Theodor Adorno comments: "Just as voluntary memory and utter oblivion always belonged together, organized fame and remembrance lead ineluctably to nothingness, the foretaste of which is perceptible in the hectic doings of all celebrities. . . The inhuman indifference and contempt instantaneously visited on the fallen idols of the culture industry reveals the truth about their fame, though without granting those disdainful of it any better hopes of posterity." ${ }^{37}$ To the extent, that is, that celebrities reach within our memories and consciousnesses, they forfeit the ability to pass into a memory that might represent real history; their imminent obsolescence, Adorno claims, prevents their passage into anything more lasting than a temporary place in the annals of publicity. This is not a revenge that is wreaked upon the celebrity in Thackeray's world, however, where in fact history and celebrity come to coincide almost completely. Adorno's unusually compensatory thesis, whereby the celebrity is barred from historical remembrance as a consequence of his or her all-too-vivid presence in modern industrialized life, does not apply to Thackeray, for whom no sort of history is finally more effective and more memorable than a history of celebrities. In this way the work of celebrity, altering

37 Minima Moralia: Reflections from Damaged Life, trans. E.F.N. Jephcott (London: Verso, 1978), pp. 100-101. 
social and even cognitive forms, extends even further-into what we might even call a historiography.

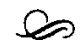

One important aspect of Thackeray's celebrities as a group is that they are at once so obviously "real," insofar as they are often factual historical figures (Wellington, Hugo, Steele), and yet so unreal in what Thackeray excludes from them. Nowhere in Thackeray's writings, for instance, do we find what we might expect of Victorian culture - the female star, such as Rachel, whose life on the stage is matched by an ineradicable personal allure. We do have Pendennis's Emily Fotheringay, but her brief career is undermined for the reader by the aromas of alcohol and poverty wafting from the dressing room. Since Thackeray's celebrities are exclusively, almost "unrealistically," male - far from the stage or entertainment, and yet so pervasively based on actual historical personages-it remains difficult to say how "real" they are. Perhaps, however, this question is finally less pertinent than the question of how celebrity as a rhetorical and cultural figure becomes a sign for reality itself in Thackeray's writing — how it becomes, finally, one of his more useful "reality effects."

Roland Barthes's well-known analysis of historical characters within fiction is pertinent here: when seen closely they are "absurdly improbable," but when seen peripherally, out of the corner of the narratorial eye, "they are superlative effects of the real." 38 If we alter the sense of Barthes's distinction somewhat, then the consequences for Thackeray become clear. By enlarging the category of the "historical character" to the "celebrity" (from Napoleon, that is, to a category where Wellington and Hurtle can coexist), and by changing the emphasis from the historical character seen on the periphery to the "brush with fame" (the fortuitous and random encounter with the charismatic figure), we see a prime example of a reality-effect not simply experienced by Thackeray's readers but by Thackeray's

38 Barthes, $S / Z$, trans. Richard Miller (New York: Hill and Wang, 1974), p. 102. 
characters as well. If the celebrity has become a "superlative effect of the real," then perhaps it is because celebrities have now become, for a novel-reading public, superlative guarantors of reality. In Thackeray's putatively realist fictions, in other words, an important category of realist technique depends upon some newly shared cultural assumptions: the celebrity, whether inside or outside of fiction, is a perfect reality-effect; and we in fact borrow our sense of reality from the celebrity-when we meet one, we have reality conferred upon us. In these assumptions Thackeray is an exemplary instance of how the celebrity not only grew in Victorian culture but also grew into one of the culture's primary indexes of what "reality" might be - the reality that the reflected glare of celebrity casts upon us.

In practice, then, our sense of Thackeray's "realism" should be redirected from the everyday and quotidian to the spectacular - but nonetheless possible, within the everydayworld of the intersection between publicity and privacy. Barthes's familiar accounts of what constitutes a reality-effectfamously, and paradigmatically, a barometer hanging on a wall, from Flaubert's Trois Contes-should in Thackeray be represented instead by very unusual encounters with celebrities: it is no longer the weather but, in a sense, the cultural figures who tell us which way the wind is blowing. ${ }^{39}$ Politically this is a world of personalization, or even - to use a term of Mary Poovey's vivification: the birthplace of a privatized, biographical, even trivialized version of historical process in which, in the words of Habermas, "the accidental fate of the so-called man in the street or that of systematically managed stars attain publicity, while publicly relevant developments and decisions are garbed in private dress and through personalization distorted to the point of unrecognizability." ${ }^{40}$ But this personalization, which brings an end to Habermas's "critical public sphere" of the

39 See Roland Barthes, "The Reality Effect," in his The Rustle of Language, trans. Richard Howard (London: Blackwell, 1986), pp. 141-48.

${ }^{40}$ Jürgen Habermas, The Structural Transformation of the Public Sphere: An Inquiry into a Category of Bourgeois Society, trans. Thomas Burger (Cambridge, Mass.: MIT Press, 1989), pp. 171-72. For an account of what Poovey calls "vivification," see her Making a Social Body: British Cultural Formation, I830-I864 (Chicago: Univ. of Chicago Press, 1995 ), p. 9 . 
eighteenth century is only possible if the "star" - the celebrity-becomes a sign for reality, not simply an escape from it. When he meets Wellington, Pendennis's entire world is suddenly floodlit by a sense of its heightened reality, and thus any one of Thackeray's characters requires access to figures of publicity in order to feel "real." The question of how real Thackeray's celebrities might be can only be answered as follows: they themselves are the ultimate form that reality takes within Thackeray's writings; they are more real than any objects, details, or private facts. In other words, the work that celebrities perform is preeminently the work of guaranteeing the reality of the world around us.

\section{Columbia University}

